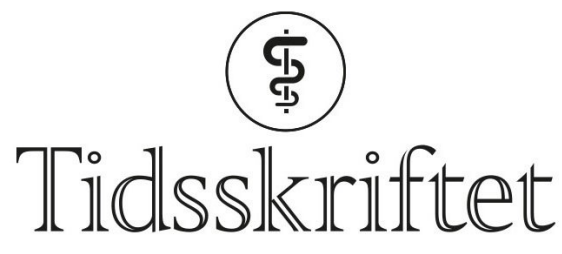

DEN NORSKE LEGEFORENING

\title{
Glymfatisk MR
}

MEDISINEN I BILDER

\section{GEIR RINGSTAD}

E-post: gringsta@ous-hf.no

Nevroradiologisk seksjon

Oslo universitetssykehus

Geir Ringstad er ph.d., spesialist i radiologi og overlege.

Forfatteren har fylt ut ICMJE-skjemaet og oppgir ingen interessekonflikter.

\section{PER KRISTIAN EIDE}

Nevrokirurgisk avdeling

Oslo universitetssykehus

og

Det medisinske fakultet

Universitetet i Oslo

Per Kristian Eide er dr.med., spesialist i nevrokirurgi, seksjonsoverlege og professor.

Forfatteren har fylt ut ICMJE-skjemaet og oppgir ingen interessekonflikter.

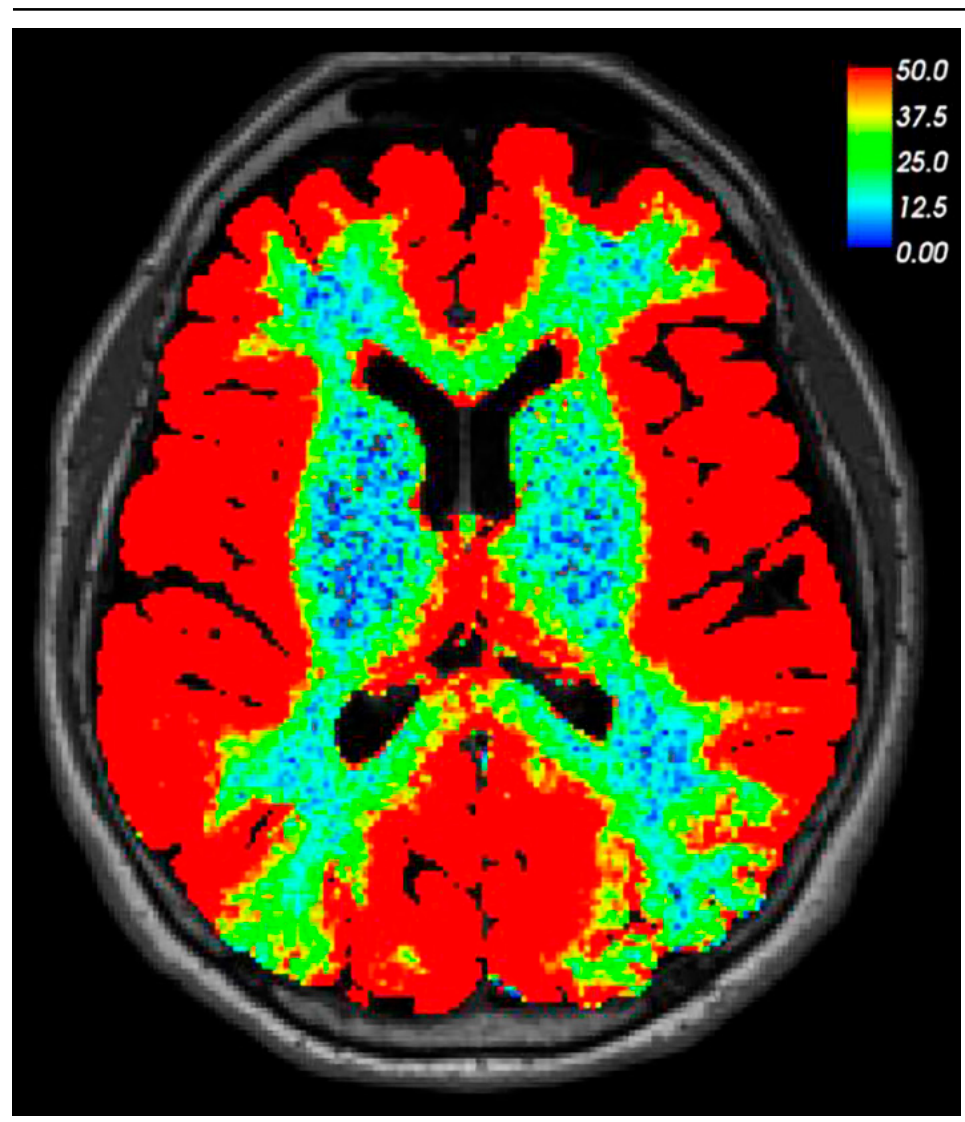

Dette MR-bildet av hjernen er tatt av en pasient 24 timer etter lumbalt innstikk og 
intratekal injeksjon av et MR-kontrastmiddel (o,5 ml gadobutrol). Pasienten var under utredning ved nevrokirurgisk avdeling på grunn av mistanke om kranial lekkasje av cerebrospinalvæske. Lekkasje kunne ikke påvises verken på bildet tatt etter 24 timer eller på tidligere tidspunkter. På dette bildet, som er basert på T1-vektet MR, har vi visualisert på en fargaskala den prosentmessige signaløkningen i hjernevevet som følger av kontrastanrikning. Bildet viser at et lite og vannløselig molekyl som gadobutrol kan anrike hele hjernen når det gis i spinalvæsken. Det har hittil vært uvisst i hvilken grad intratekalt injiserte legemidler kan anrike hjernevevet hos mennesker. Gitt at kontrastmiddelet ikke kan lekke inn i blodet gjennom den intakte blod-hjerne-barrieren, kan vi her slå fast at all anrikning av hjernen finner sted på utsiden av blodårene.

Siden de fleste legemidler gitt peroralt eller intravenøst ikke slipper ut gjennom blodåreveggene i hjernen, kan kunnskapen om veien inn til hjernen fra spinalvæsken åpne for nye måter å diagnostisere og behandle hjernesykdommer. Den kan også kaste lys over hvordan meningeale lymfeårer kan påvirke hjernen via cerebrospinalvæsken (1).

Mye tyder på at MR-kontrastmiddelet anriker hjernen via det såkalte glia-lymfatiske eller "glymfatiske» systemet, som ble beskrevet første gang i 2012 (2). Her fungerer spinalvæsken som et transportmedium for utskillelsen av avfallsstoffer som amyloid- $\beta$ og tau-protein fra hjernen langs perivaskulærrommene (en form for «hjernevask»). Det er grunn til å tro at gadobutrol vaskes ut fra hjernen langs samme rute som disse avfallsstoffene. Ved glymfatisk MR er det vist at denne utskillelsen er redusert hos pasienter med en type demens (normaltrykkshydrocephalus) (3).

\section{LITTERATUR:}

1. Louveau A, Plog BA, Antila S et al. Understanding the functions and relationships of the glymphatic system and meningeal lymphatics. J Clin Invest 2017; 127:3210-9. [PubMed][CrossRef]

2. Iliff JJ, Wang M, Liao Y et al. A paravascular pathway facilitates CSF flow through the brain parenchyma and the clearance of interstitial solutes, including amyloid $\beta$. Sci Transl Med 2012; 4: 147ra111. [PubMed][CrossRef]

3. Ringstad G, Valnes LM, Dale AM et al. Brain-wide glymphatic enhancement and clearance in humans assessed with MRI. JCI Insight 2018; 3: 121537. [PubMed][CrossRef]

Publisert: 6. januar 2020. Tidsskr Nor Legeforen. DOI: 10.4045/tidsskr.19.0651

Mottatt 10.10.2019, første revisjon innsendt 28.11.2019, godkjent 5.12.2019.

(C) Tidsskrift for Den norske legeforening 2020. Lastet ned fra tidsskriftet.no 